\title{
Development Involvement and Property Share Performance; International Evidence
}

Citation for published version (APA):

Eichholtz, P. M. A., \& Brounen, D. (2004). Development Involvement and Property Share Performance; International Evidence. Journal of Real Estate Finance and Economics, 29(1), 79-97. https://doi.org/10.1023/B:REAL.0000027202.57984.21

Document status and date:

Published: 01/01/2004

DOI:

10.1023/B:REAL.0000027202.57984.21

Document Version:

Publisher's PDF, also known as Version of record

\section{Please check the document version of this publication:}

- A submitted manuscript is the version of the article upon submission and before peer-review. There can be important differences between the submitted version and the official published version of record.

People interested in the research are advised to contact the author for the final version of the publication, or visit the DOI to the publisher's website.

- The final author version and the galley proof are versions of the publication after peer review.

- The final published version features the final layout of the paper including the volume, issue and page numbers.

Link to publication

\footnotetext{
General rights rights.

- You may freely distribute the URL identifying the publication in the public portal. please follow below link for the End User Agreement:

www.umlib.nl/taverne-license

Take down policy

If you believe that this document breaches copyright please contact us at:

repository@maastrichtuniversity.nl

providing details and we will investigate your claim.
}

Copyright and moral rights for the publications made accessible in the public portal are retained by the authors and/or other copyright owners and it is a condition of accessing publications that users recognise and abide by the legal requirements associated with these

- Users may download and print one copy of any publication from the public portal for the purpose of private study or research.

- You may not further distribute the material or use it for any profit-making activity or commercial gain

If the publication is distributed under the terms of Article $25 \mathrm{fa}$ of the Dutch Copyright Act, indicated by the "Taverne" license above, 


\title{
Development Involvement and Property Share Performance: International Evidence
}

\author{
DIRK BROUNEN \\ Erasmus University Rotterdam, Rotterdam, The Netherlands \\ E-mail:d.brounen@fbk.eur.nl
}

PIET EICHHOLTZ

University of Maastricht, Maastricht, The Netherlands

E-mail: p.eichholtz@berfin.unimaas.nl

\begin{abstract}
This paper concerns the dilemma whether regulators should preclude tax-exempt property investment companies from engaging in property development activities. We analyze the economic effects of combinations of property investment and property development by looking at the performance of an international set of property investment companies with varying degrees of involvement in property development. We study the five most important listed property markets in the world: the United States, Hong Kong, Australia, the United Kingdom and France. We examine the extent to which property investment companies participate in development projects by dividing the book value of their development projects by total assets. These development ratios yield remarkable differences both within and across national samples, with national averages varying between 2.23 percent for the United States and 21.34 percent for our Hong Kong sample. Analysis of property share performance yields results that consistently indicate that the cluster of property companies most involved in development projects is associated with both the highest total return and the highest systematic risk. We also find a weak positive link between development involvement and the Jensen alpha of property shares. The statistical significance of this link varies by country, with strong results for Hong Kong and Australia and less compelling results for the United States, the United Kingdom and France. Besides analyzing the stock performance of the companies in our samples we also focus on their operational profitability. Again, we consistently find both the highest and most volatile performance for companies actively participating in property development projects.
\end{abstract}

Key Words: listed property companies, property development, risk adjustment

\section{Introduction}

In an increasing number of countries, property investment companies can attain a taxexempt status. In order to maintain fair competition with property development companies paying corporate taxes, these tax-exempt property investment companies are very often prohibited from involvement in development activities. For example, the legal framework encompassing U.S. Real Estate Investment Trusts (REITs) limits the amount of real estate development these companies can participate in. When violating these restrictions, REITs can lose their beneficial tax-transparent status and thereby lose a significant portion of their appeal to outside investors. 
Outside of the United States, the tax authorities in Australia, Belgium, Canada, France, Japan, The Netherlands, Singapore, South Africa and South Korea all grant property investment companies a tax-transparent status very similar to the U.S. REIT system. Besides that, tax-transparency of property investment vehicles exists in Germany, Austria and Switzerland, where the open-ended property funds are eligible for exemption of corporate taxes. However, the structure of these funds is quite different from that of U.S. REITs. Restrictions regarding property development participations differ strongly across these countries. In some countries like Belgium and The Netherlands property development activities are completely off-limits for tax-transparent real estate investment companies, the so-called bevaks and fiscale beleggingsinstellingen. This also holds for the open-ended funds in the German-speaking countries. Regulators quote fair competition and a need to limit the taking of active risks by these investment vehicles as reasons for this restriction.

In other countries like France these limitations are less strict and in countries without tax-transparency for property companies, they are nonexistent. In the absence of regulations prohibiting property investment companies from it, active development involvement appears to be quite common, either for ones own portfolio or for third parties. ${ }^{1}$ The fact that combining investment and development by property companies is normal without regulatory interference to the contrary, suggests that this combination makes economic sense and that positive returns can be reaped from it. If that would be the case, precluding the combination with a tax penalty would be bad for economic efficiency. In this paper, we try to shed light on this issue by looking at the performance of an international set of property companies who are to differing degrees active in property development.

For an investor, it may make sense to start development activities since these give access to the most attractive investment opportunities and locations. According to this argument, investors are always last in line when projects come on the market, and adding development activities allows them to advance in that line. For emerging markets, this argument may hold even more than for mature property markets, since the stock of existing properties is relatively small in those markets, and the only way to invest at all is by developing for one's own portfolio.

For a property developer, keeping projects in one's own investment portfolio can be justified by arguing that this can decrease the dependency on the capital market. By combining property investment and development activities within one entity, firm management can use the steady stream of income from an investment portfolio to finance profitable development projects, even in times when capital markets are not interested in real estate projects.

However, there are also strong arguments against the combination of property investment and development in one company. First, the management expertise necessary for property investment is different from what is needed for property development. Managing both disciplines within one firm may decrease corporate efficiency, causing spills and thereby diminishing firm value. Recent studies by Capozza and Seguin (1999) and Eichholtz et al. (2000) offer evidence that indicates that corporate diversification causes informational asymmetries, which decrease both firm value and stock performance in the U.S. REIT market. According to both studies firm management should focus its 
corporate resources on one sector or discipline, enhancing firm value by yielding specialists advantages.

Also, analysts and property share investors generally seem to like focussed companies because of their transparency, which may be lost by combining different activities like property investment and development. Development is a very cyclical business and property development companies are associated with relatively high systematic risk, as we will subsequently show. Property investment companies' shares, on the other hand, are regarded as defensive, with a low systematic risk. Combining the two activities provides the investor with an unclear profile, which may be undesirable.

Despite the relevance for property companies and their investors, the relationship between property development activities and firm performance has not been investigated very deeply. Brounen, Eichholtz and Kanters (2000) have looked into this issue, but only for U.S. REITs. As we already noted, the extent to which REITs develop their own properties is quite limited. Since the cross-sectional variation in the degree of property development undertaken by listed property companies in most countries is far greater than it is in the United States, we hope to generate new insights by investigating this issue internationally. Besides broadening the sample internationally we also extend the sample period to one full real estate cycle and analyze these samples using more sophisticated methodology.

In this paper, we analyze both the level of property development involvement and the stock and operational performance of property companies originating from five of the most important listed property markets: the United States, Hong Kong, Australia, the United Kingdom and France. The paper starts with an overview of the literature regarding the performance of listed property companies. After that, we discuss our sample, which consists of 331 listed property companies for the period 1987-2000. We also briefly analyze the data in this section, and find that property development is undertaken mainly by large listed property investment companies. The following section describes the methodology, which is used for subsequent analysis. In Section 5, we present our empirical results on both the property development involvement ratios and on the corresponding stock and operational performance. The outcomes exhibit a consistent and positive relationship between the degree of property development and property companies' stock returns and risks. When controlling for differences in systematic risks by applying a single index market model most of the spread in stock returns disappears. The analysis of operational profitability results in a steady pattern, and shows that property-developing firms outperform the sample average during economic prosperity and underperform when the economy slows down. This pattern illustrates our previous results that the market sensitivity is highest for developing companies. Finally, we summarize these findings in our conclusions and offer some suggestions for further research.

\section{Literature}

When studying the relationship between firm activities and stock performance we first need a thorough understanding of the risk-return characteristics of listed property 
companies. Fortunately these risk-return characteristics are well documented by a great deal of research. Titman and Warga (1986) were the first to analyze the risk-adjusted performance of a sample of U.S. REITs for the period 1973-1982 using both single index (i.e., CAPM) and multiple index (i.e., APT) models. Their results differ substantially depending on the model specification, however, in ranking the performance of individual REITs the choice of model specification appeared relatively unimportant. Later studies like Chan et al. (1990), Eichholtz and Huisman (2000) and Ling and Naranjo (2002) have shown similar findings. Since our study focusses on the cross-sectional variation of stock performance of listed property, we will apply a single index model in combination with the most appropriate benchmarks.

Regarding the risk and return characteristics of real estate development projects, academic literature is less abundant. Most of the existing literature relating to development activities focusses on the typical construction cycles within the real estate industry. Wheaton (1987) and Grenadier (1995) documented that developers tend to start new projects during favorable conditions. The underlying time-to-build lag, however, often causes the resulting new space to enter a market that has turned less favorable. These studies, therefore, imply that participating in property development projects can increase a firm's exposure to the overall property cycle and increase its market risk.

Whether different activities should be combined under one roof is a matter of corporate diversification, for which a rich literature is available. Early research like Weston (1970) and Lewellen (1971) promoted a spread of corporate activities by stressing the financial benefits that could be reaped from internal capital flows and coinsurance of cash flows. Since the early 1980s, however, academic research has been emphasizing the costs that arise when firms combine multiple activities. Corporate diversification create a loss of information asymmetry, since the internal organization grows more complex. Denis et al. (1997) discuss these informational asymmetries and the resulting agency costs that lower firm value. Montgomery (1994) discusses the existing empirical literature and concludes that, although there is no consensus, most of the outcomes so far reveal a negative relationship between corporate diversification and stock performance. Recent studies by Capozza and Seguin (1999) and Eichholtz et al. (2000) examine the issue of corporate diversification for a sample of U.S. REITs and conclude that corporate diversification among property investment companies tends to decrease both firm value and stock performance. Considering these lessons, we might wonder whether property development and property investment activities should be mixed in one company, or whether agency costs hamper the synergies that might arise.

Until today academic evidence of the explicit relationship between property development and the performance of real estate investment companies has been scarce. Brounen et al. (2000) have examined the issue for a set of U.S. equity-REITs for the period 1993-1999. Using an APT-based risk adjustment model proposed by Litt and Mei (1999), they decomposed the risks of the REITs and documented proportional increases of the systematic risk component associated with the involvement in development projects. After correcting REIT-stock returns for these differences in the underlying risk profiles a modest outperformance remained for developing REITs. In this paper, we extend their study by 
broadening the sample to at least one full property cycle and to five countries and by broadening the methodological approach.

\section{Data}

In our study, we examine property companies listed in the five most important public property markets in the world: the United States, Hong Kong, Australia, the United Kingdom and France. In our sample selection procedure, we balance international coverage and statistical requirements by including only national samples with sufficient observations for academic research. We include international markets in order to analyze whether the patterns reported by Brounen et al. (2000) for the United States, also hold in an international context where the variation in property development versus investment activities is much greater than in the United States. We collect our universe of property companies for all five countries from the Global Property Research (GPR) Database. ${ }^{2}$

Next, we assemble the monthly total return series of all companies for the period January 1987 through December 2000 using the GPR Database as main datasource. To correct these series for fluctuations in the risk-free rate of return, we use the one-month Government Bond rate of the corresponding countries. For our single index market model analysis we use two model specifications; one in which we use the GPR-General National indices, indices which mimic the performance of the property companies in our samples, and a second specification in which we use the broader MSCI National stock indices. The GPR-index model will result in betas that are close to one and provide us with insights of the firms' real estate market risks. The second, more common, MSCI-specification will result in lower individual betas, but offers a distinction along the real "market" risk of each company in our samples. The necessary time series on the risk free rates of return and market indices were obtained from Datastream Advance and Bloomberg. To illustrate the cross-national variation in performance over the sample period we plot the different market indices in Figure 1, while return information on a country-by-country basis is given in Table 1. All returns are expressed in local currencies.

Figure 1 and the statistics in Table 1 both clearly illustrate the differences in performance of the listed property markets in our sample. The Hong Kong market is known for its volatile swings in returns, with strong booms in the early- and mid-1990s and an even stronger slump during the Asian crisis, which started in the summer of 1997. The French market represents the other end of the spectrum, offering very modest and stable returns over the complete sample period. The U.S. market lies in between both extremes, offering a fairly stable return besides slumps in the late 1980s and 1990s.

Before we focus on the individual firm involvement in property development activities we briefly analyze the underlying national property markets using international statistics. The construction figures published in the Market Profiles of the Urban Land Institute (ULI) for the sample period clearly show the cyclical trends common to the property development industry. For all countries ULI reports high construction activity in economic booms, while economic slumps are consistently associated with low construction figures. But besides a significant variation through time we also detect a distinct difference in 


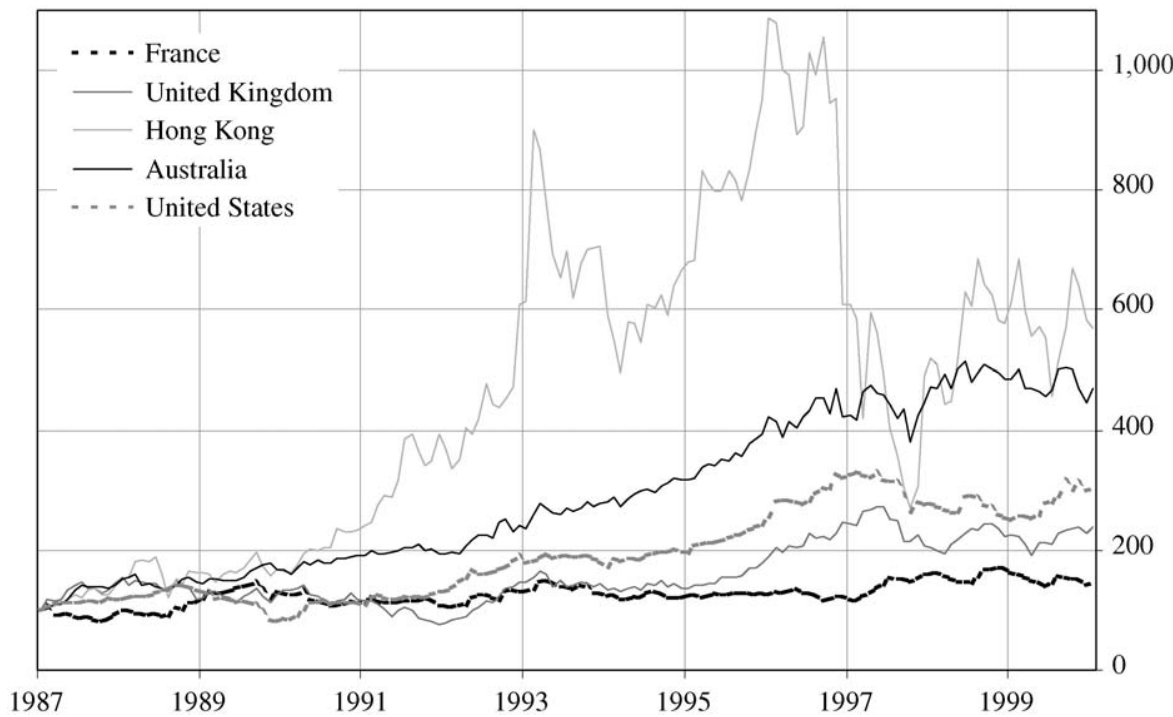

Figure 1. The market developments for the period December 1987 until December 2000 based on the GPRGeneral indices (December $1987=100$ ).

Source. Global Property Research.

Table 1. Market statistics.

\begin{tabular}{lrrrrr}
\hline & \multicolumn{5}{c}{ GPR-General (\%) } \\
\cline { 2 - 6 } & \multicolumn{1}{c}{ U.S. } & Hong Kong & Australia & \multicolumn{1}{c}{ U.K. } & France \\
\hline Mean monthly return & 0.68 & 1.09 & 0.98 & 0.46 & 0.22 \\
Mean annualized return & 8.48 & 13.87 & 12.40 & 5.62 & 2.63 \\
Monthly standard deviation & 4.08 & 11.92 & 4.43 & 5.90 & 4.45 \\
Minimum monthly return & -14.61 & -36.09 & -12.59 & -12.95 & -10.14 \\
Maximum monthly return & 10.46 & 59.85 & 11.72 & 13.83 & 10.84 \\
\hline
\end{tabular}

Notes. In this table, we report the market statistics of the national listed property markets from which the companies in our sample originate. The return data relate to total return time series denoted in local currencies. Source. Global Property Research.

construction activity among the different nations in our sample. For Hong Kong, for instance, we find an average construction-inventory ratio during the sample period equal to 5.95 percent, whereas the French ratio of 1.49 percent implies a significantly lower national property development activity. To explain this cross-national variation one needs to take differences in natural boundaries, legislation and regional economics into account. When turning from this national macro-perspective towards an analysis on a micro-level, by studying the construction activity of the individual companies in each sample, we detect similar differences.

For analyzing the relative weight of property development activities within individual 
Table 2. National sample distributions.

\begin{tabular}{|c|c|c|c|c|}
\hline \multirow[b]{2}{*}{ Cohorts $^{2}$} & \multicolumn{4}{|c|}{ Sample Statistics ${ }^{1}$} \\
\hline & $N$ & $\begin{array}{l}\text { Mean Development } \\
\text { Ratio }(\%)\end{array}$ & $\begin{array}{l}\text { Mean Market } \\
\text { Cap }\end{array}$ & $\begin{array}{l}\text { Mean } \\
\text { Debt-Ratio }\end{array}$ \\
\hline United States & 157 & 2.23 & 793 & 0.48 \\
\hline Developing & 48 & 6.02 & 939 & 0.51 \\
\hline Semi-developing & 39 & 1.09 & 881 & 0.48 \\
\hline Non-developing & 60 & 0.00 & 598 & 0.47 \\
\hline Hong Kong & 42 & 21.34 & 1.525 & 0.20 \\
\hline Highly developing & 12 & 42.61 & 2.598 & 0.23 \\
\hline Medium developing & 14 & 20.08 & 1.419 & 0.19 \\
\hline Hardly developing & 17 & 4.85 & 859 & 0.18 \\
\hline Australia & 60 & 3.06 & 341 & 0.25 \\
\hline Developing & 16 & 14.72 & 426 & 0.28 \\
\hline Semi-developing & 5 & 1.30 & 375 & 0.18 \\
\hline Non-developing & 39 & 0.00 & 248 & 0.25 \\
\hline United Kingdom & 62 & 3.62 & 445 & 0.39 \\
\hline Developing & 20 & 10.88 & 475 & 0.42 \\
\hline Semi-developing & 12 & 1.49 & 452 & 0.38 \\
\hline Non-developing & 30 & 0.00 & 426 & 0.39 \\
\hline France & 19 & 4.84 & 338 & 0.38 \\
\hline Developing & 6 & 15.33 & 449 & 0.41 \\
\hline Non-developing & 13 & 0.00 & 287 & 0.36 \\
\hline
\end{tabular}

Notes. In this table, we report the sample statistics relating to the firms in each of national samples. The Development ratios are defined as the ratio between the book value of development projects and the firm's total assets. The market caps are denoted in millions of US\$ as of September 2000, while the debt ratios are computed for January 2000.

${ }^{1}$ The $t$-statistic measures the statistical significance of the difference between the mean market caps and debtratios (DR) of the property developing and non-property developing clusters. $T$-stats marked with $*$ are significantly different from zero at the 90 percent-confidence level.

${ }^{2}$ Development cohorts are based on the average size of the companies' development activities. Companies in the Developing cohort participate in development projects to an extent that exceeds the national sample average, Semi-developing are firms which do participate in development projects but to an extent that is less than the sample average. The Non-developing cohort contains companies that do not participate in any development projects at all. For the Hong Kong sample an exception has been made since all companies are involved in development projects. Therefore, we divided the Hong Kong sample into Highly, Medium and Hardly developing cohorts, which are based on the national sample means plus and minus 1 standard deviation of the development ratio. Due to sample size limitations we divided the French sample into two cohorts, the Developing and the Nondeveloping cohorts.

Source. Global Property Research and Datastream.

property companies we derive property development involvement ratios, which divide the book value of the development projects by total assets. The necessary firm-specific data for this exercise were gathered from the annual report archive of GPR. Table 2 presents the aggregated results for the development involvement ratios. In the following step of our analysis, we categorize each company within its national sample into one of three cohorts. We first take out all the companies that do not develop at all, and classify them into the 
cohort called non-developing companies. Next, we calculate for each country the average degree to which companies participate in development projects. We then classify the companies that participate in property development to a level less than this national average in a category we call semi-developing companies. The remaining companies are the ones that develop property to a scale that exceeds this national average and are therefore classified as developing companies. The sample distribution across these cohorts is presented in Table $2 .^{3}$ Because of sample limitations we restricted our classification of the firms in our French sample into developing and non-developing firms. In our Hong Kong sample all property companies were involved in property development, therefore we classified Hong Kong companies into highly, medium and lightly developing categories. Again, we used the national average as benchmark and classified firms that exceeded this average by more than one standard deviation as highly developing, while firms that developed to a degree that was more than one standard deviation below this average are called lightly developing.

The national averages of these development involvement ratios vary in a way that corroborates with our previous findings regarding the national construction activities. Hong Kong companies participate the most in development projects, whereas the French sample contains the lowest average in this respect. For each cohort we then collect information on the size of the company, the debt ratio, and the underlying property type in order to find out whether cross-sectional patterns in these factors between the different development cohorts exist. Concerning company size we find in each market that the average size of property developing companies exceeds the size of nondevelopers. This may be due to the fact that property development requires a certain critical mass in order to create significant spin-offs. With respect to debt financing we find higher levels of debt for developers than for nondevelopers in each sample except for France. Property development projects are typically financed using temporary construction loans, which eventually are replaced by long-term loans after the project is finalized. This widespread use of debt in the industry can possibly account for this difference in the overall debtlevels with respect to the development activities. Regarding the underlying property type in which the companies in our sample are investing we find results that are less robust across the different national samples. Our results vary strongly across countries and indicate that property companies focussing on retail property generally exhibit the most distinct preference for development involvement, whereas recreational and industrial specialists hardly develop property at all.

\section{Methodology}

In our study, we apply different approaches to compare the returns of property developing companies with companies that do not participate in development. We start with a simple comparative analysis in which we derive and compare mean annual total returns for the different cohorts. We compare the average annual total returns of each category with the corresponding market returns to quantify a plain relative performance. To give a first impression of the differences in risk, we derive the corresponding mean standard 
deviations for each cohort. By dividing the mean excess returns of a stock by the standard deviation of its total returns we derive the traditional Sharpe (1966) index:

$$
S I_{i}=\frac{\bar{R}_{i}-\bar{R}_{f}}{\sigma_{i}},
$$

where $R_{i}$ is the average return of the stock, $R_{f}$ is the risk free rate of return, and $\sigma_{i}$ is the standard deviation of stock returns. Using the Sharpe index we offer a first glance of the risk-adjusted return performance of the different cohorts.

The main part of our analysis is focussed on the Jensen (1969) alpha. The Jensen alpha is the difference between the mean total return earned by a stock and the equilibrium return that should have been earned by the stock given the market conditions and the risk of the stock. In other words, the Jensen alpha is the intercept in the regression of stock excess returns on the market excess returns:

$$
\alpha_{i}=R_{i}-\left(R_{f}+\beta_{i}\left(R_{m}-R_{f}\right)\right)+\varepsilon_{i},
$$

where $R_{m}$ is the average return on the market, $\beta_{i}$ is the sensitivity of the stock's excess return with respect to the market excess return, the systematic risk, and $\varepsilon_{i}$ is an error term.

In order to isolate the relationship between property development involvement and the risk $\beta_{i}=c+\gamma_{1} \mathrm{COUNTRY}_{i}+\gamma_{2} \mathrm{DEV}_{i}+\gamma_{3} \mathrm{DR}_{i}+\gamma_{4} \mathrm{SIZE}_{i}+\gamma_{5} \mathrm{MTB}_{i}+\varepsilon_{i}$ and return characteristics we perform multivariate regression analysis. These models relate the observed firm alpha, beta and sigma to dummy variables that indicate the country of origin $^{4}$ and to development involvement (DEV), ${ }^{5}$ the firm debt-ratio (DR), firm size (SIZE), and the market-to-book ratio $(\mathrm{MTB})^{6}$ as potential explanatory variables for crosssectional variation.

$$
\begin{aligned}
& \alpha_{i}=c+\gamma_{1} \text { COUNTRY }_{i}+\gamma_{2} \operatorname{DEV}_{i}+\varepsilon_{i}, \\
& \alpha_{i}=c+\gamma_{1} \text { COUNTRY }_{i}+\gamma_{2} \text { DEV }_{i}+\gamma_{3} \mathrm{DR}_{i}+\gamma_{4} \mathrm{SIZE}_{i}+\gamma_{5} \mathrm{MTB}_{i}+\varepsilon_{i}, \\
& \beta_{i}=c+\gamma_{1} \mathrm{COUNTRY}_{i}+\gamma_{2} \mathrm{DEV}_{i}+\varepsilon_{i} .
\end{aligned}
$$

In the fourth and last phase of our analysis we focus on the operational profits of the companies in our samples. Stock returns can be influenced by the sentiment of the general stock market, which is why we add an alternative analysis looking at operational profits of the property companies in our samples. The findings of this part of the analysis will be independent of stock market sentiments. We measure the operational profitability of a company by analyzing the return on capital employed (RCE) ratio. ${ }^{7}$ This ratio is calculated by dividing the sum of pre-tax profits and interest charges by the net capital employed, 
which represents total capital employed adjusted for short-term borrowings, future income tax benefits and total intangibles:

$$
\mathrm{RCE}=\frac{\text { Pre-tax Profits }+ \text { Total Interest Charges }}{\text { Net Capital Employed }} * 100 \%
$$

where pre-tax profits are the pre-tax profit, including associates, adjusted for extraordinary items, nonoperating provisions and exchange profits and losses. Total interest charges are the sum total of the interest on bank and convertible loans, bonds, and debentures. Net capital employed is the sum of the total capital employed, borrowings repayable within one year minus total intangibles and future income tax benefits. Datastream Advance offers these RCEs over time for all national samples, except for the United States, for which we use a proxy by dividing pre-tax operating profits by total assets.

\section{Results}

After having identified which companies are involved in property development operations we turn to the first phase of our performance analysis. In this phase, we compute the average annual total return for each cohort. For the sake of comparison, we also state the corresponding national sample average returns and compare cluster averages in order to derive relative performance. The results in Table 3 show that in each national sample we find the highest average annual total returns for the cohort of companies that involved the most in development projects. However, this difference in average return per cohort is never statistically significant, so this result has to be interpreted with caution. In the United States sample, for instance, REITs categorized as developers have outperformed the national mean with 0.44 percent per annum, on average. U.S. property companies that do not participate in any development activities, on the other hand, have underperformed their peers with 0.65 percent, on average. The spread in relative returns varies across national samples, but is favorable for the developers in each market, with Hong Kong and Australia exhibiting the largest spread in total returns.

In order to take differences in volatility into account we also compute the monthly standard deviations, which represent the total risks of the companies involved. By dividing the monthly excess returns by the corresponding standard deviation of returns, we derive Sharpe indices for each company in our sample. By averaging these Sharpe indices for the different cohorts we obtain a first impression of the relative risk-return characteristics of the development involvement clusters. The results stated in Table 3 show that besides offering the highest average total returns, property-developing firms also offer the highest total risks. For each national sample, we document the highest average standard deviation for the property developing cohorts. After combining both the return and risk results into the Sharpe index we consistently find higher Sharpe index levels for developers than for nondevelopers, indicating that the developing property companies yield the highest reward for their volatility. These results suggest that even after taking the differences in total risks 
Table 3. Comparative analysis.

\begin{tabular}{|c|c|c|c|c|c|}
\hline Cohorts $^{1}$ & $\begin{array}{l}\text { Average Annual } \\
\text { Total Return }(\%)\end{array}$ & $\begin{array}{l}\text { Relative } \\
\text { Performance }^{2}(\%)\end{array}$ & $\begin{array}{l}\text { Monthly Standard } \\
\text { Deviation }(\%)\end{array}$ & $\begin{array}{l}\text { Sharpe } \\
\text { Ratio }^{3}\end{array}$ & $\begin{array}{l}t \text {-Test }{ }^{4} \\
\text { Difference }\end{array}$ \\
\hline \multicolumn{6}{|l|}{ United States } \\
\hline Developing & 8.42 & +0.44 & 3.75 & 0.13 & \multirow[t]{4}{*}{1.63} \\
\hline Semi-developing & 8.30 & +0.32 & 3.39 & 0.11 & \\
\hline Non-developing & 7.33 & -0.65 & 3.62 & 0.10 & \\
\hline Sample Average & 7.98 & - & 3.38 & 0.11 & \\
\hline \multicolumn{6}{|l|}{ Hong Kong } \\
\hline Highly developing & 13.12 & +0.85 & 13.75 & 0.06 & \multirow[t]{4}{*}{0.52} \\
\hline Medium developing & 10.50 & -1.77 & 10.55 & 0.05 & \\
\hline Hardly developing & 11.17 & -1.10 & 11.47 & 0.04 & \\
\hline Sample Average & 12.27 & - & 10.89 & 0.05 & \\
\hline \multicolumn{6}{|l|}{ Australia } \\
\hline Developing & 12.71 & +1.54 & 13.97 & 0.18 & \multirow[t]{4}{*}{1.18} \\
\hline Semi-developing & 7.78 & -0.31 & 10.60 & 0.10 & \\
\hline Non-developing & 8.49 & -1.01 & 11.17 & 0.08 & \\
\hline Sample Average & 9.50 & - & 10.94 & 0.10 & \\
\hline \multicolumn{6}{|l|}{ United Kingdom } \\
\hline Developing & 7.58 & +0.73 & 8.33 & 0.12 & \multirow[t]{4}{*}{1.40} \\
\hline Semi-developing & 6.51 & -0.34 & 5.15 & 0.08 & \\
\hline Non-developing & 6.37 & -0.48 & 4.73 & 0.08 & \\
\hline Sample Average & 6.85 & - & 5.36 & 0.09 & \\
\hline \multicolumn{6}{|l|}{ France } \\
\hline Developing & 4.49 & +0.39 & 4.42 & 0.04 & \multirow[t]{3}{*}{0.16} \\
\hline Non-developing & 3.92 & -0.18 & 3.02 & 0.03 & \\
\hline Sample Average & 4.10 & - & 3.15 & 0.03 & \\
\hline
\end{tabular}

Notes

${ }^{1}$ Development cohorts are based on the average size of the companies' development activities. Companies in the Developing cohort participate in development projects to an extent that exceeds the national sample average, Semi-developing are firms which do participate in development projects but to an extent that is less than the sample average. The Non-developing cohort contains companies that do not participate in any development projects at all. For the Hong Kong sample exception has been made since all companies are involved in development projects. Therefore, we divided the Hong Kong sample up into Highly, Medium and Hardly developing cohorts, which are based on the national sample means plus and minus 1 standard deviation of the development ratio. Due to sample size limitations we divided the French sample up into two cohorts, the Developing and the Non-developing cohorts.

${ }^{2}$ Relative performance is measured as the difference between the total return of the cluster and the national sample average.

${ }^{3}$ The Sharpe ratio is calculated by dividing the mean excess return by the standard deviation of the total returns.

${ }^{4}$ The $t$-statistic measures the statistical significance of the difference between the mean Sharpe ratios of the property developing and non-property developing clusters.

Source. Global Property Research.

into account, property-developing firms tend to outperform their nondeveloping peers. However, in order to measure the risk-adjusted performance of the individual property companies more accurately we need to apply more sophisticated measures like the Jensen alpha. 


\subsection{Single index model}

By regressing the monthly excess stock returns on the corresponding excess market returns we derive estimates for the alpha, beta, and sigma of each individual company in our sample. We run each individual regression twice, first using the GPR-National property indices as market index and then using the broader MSCI-Nationals. We aggregate the coefficient estimates of both specifications along each cohort to find out whether differences exist along development participation levels. The results of these efforts are reported in Table 4 and show that developing companies are generally associated with the highest risk-adjusted outperformance, or Jensen alpha, in each of the national samples in

Table 4. Property stock performance analysis.

\begin{tabular}{|c|c|c|c|c|c|c|}
\hline \multirow[b]{2}{*}{ Benchmark } & \multicolumn{3}{|c|}{ MSCI } & \multicolumn{3}{|c|}{ GPR General } \\
\hline & Mean & Median & $\begin{array}{l}t \text {-Test } \dagger \\
\text { Difference }\end{array}$ & Mean & Median & $\begin{array}{l}t \text {-Test } \\
\text { Difference }\end{array}$ \\
\hline \multicolumn{7}{|l|}{ A: United States } \\
\hline Jensen Alpha & 0.003 & 0.004 & & 0.000 & 0.001 & \\
\hline Developing & 0.003 & 0.004 & & 0.001 & 0.001 & \\
\hline Semi-developing & 0.003 & 0.003 & 0.555 & 0.000 & 0.001 & 0.385 \\
\hline Non-developing & 0.002 & 0.003 & & 0.000 & 0.001 & \\
\hline Beta & 0.159 & 0.153 & & 0.998 & 0.994 & \\
\hline Developing & 0.205 & 0.165 & & 1.081 & 1.066 & \\
\hline Semi-developing & 0.167 & 0.158 & 1.387 & 0.985 & 0.957 & $1.812 *$ \\
\hline Non-developing & 0.114 & 0.147 & & 0.916 & 0.948 & \\
\hline$R^{2}$ & & 0.038 & & & 0.304 & \\
\hline \multicolumn{7}{|l|}{ B: Hong Kong } \\
\hline Jensen Alpha & 0.000 & -0.001 & & 0.000 & -0.001 & \\
\hline Highly developing & 0.007 & 0.010 & & 0.007 & 0.011 & \\
\hline Medium developing & 0.006 & -0.001 & $2.103 * *$ & 0.007 & -0.001 & $2.241 * *$ \\
\hline Hardly-developing & -0.016 & -0.012 & & -0.016 & -0.011 & \\
\hline Beta & 1.116 & 1.109 & & 1.001 & 1.001 & \\
\hline Highly developing & 1.368 & 1.485 & & 1.154 & 1.078 & \\
\hline Medium developing & 1.094 & 1.055 & 1.751 & 1.013 & 0.994 & $1.893 *$ \\
\hline Hardly-developing & 0.983 & 0.899 & & 0.848 & 0.847 & \\
\hline$R^{2}$ & & 0.475 & & & 0.357 & \\
\hline \multicolumn{7}{|l|}{ C: Australia } \\
\hline Jensen Alpha & 0.002 & 0.003 & & 0.000 & 0.001 & \\
\hline Developing & 0.006 & 0.008 & & 0.003 & 0.002 & \\
\hline Semi-developing & 0.003 & 0.003 & $1.998 * *$ & -0.001 & 0.000 & 1.389 \\
\hline Non-developing & 0.000 & 0.002 & & -0.001 & 0.001 & \\
\hline Beta & 0.325 & 0.344 & & 1.022 & 1.057 & \\
\hline Developing & 0.348 & 0.441 & & 1.170 & 1.140 & \\
\hline Semi-developing & 0.376 & 0.354 & 0.431 & 1.002 & 1.069 & 1.284 \\
\hline Non-developing & 0.305 & 0.344 & & 0.977 & 0.989 & \\
\hline$R^{2}$ & & 0.115 & & & 0.375 & \\
\hline
\end{tabular}


Table 4. (continued)

\begin{tabular}{|c|c|c|c|c|c|c|}
\hline \multirow[b]{2}{*}{ Benchmark } & \multicolumn{3}{|c|}{ MSCI } & \multicolumn{3}{|c|}{ GPR General } \\
\hline & Mean & Median & $\begin{array}{l}t \text {-Test } \dagger \\
\text { Difference }\end{array}$ & Mean & Median & $\begin{array}{l}t \text {-Test } \\
\text { Difference }\end{array}$ \\
\hline \multicolumn{7}{|l|}{ D: United Kingdom } \\
\hline Jensen Alpha & 0.009 & 0.009 & & 0.001 & 0.001 & \\
\hline Developing & 0.010 & 0.012 & & 0.002 & 0.004 & \\
\hline Semi-developing & 0.008 & 0.009 & 0.929 & 0.000 & 0.002 & 0.747 \\
\hline Non-developing & 0.008 & 0.009 & & 0.000 & 0.000 & \\
\hline Beta & 0.400 & 0.301 & & 1.006 & 1.032 & \\
\hline Developing & 0.422 & 0.409 & & 1.184 & 1.128 & \\
\hline Semi-developing & 0.403 & 0.376 & 0.426 & 1.048 & 1.084 & $2.526^{* *} *$ \\
\hline Non-developing & 0.386 & 0.304 & & 0.881 & 0.990 & \\
\hline$R^{2}$ & & 0.054 & & & 0.259 & \\
\hline \multicolumn{7}{|l|}{ E: France } \\
\hline Jensen Alpha & 0.005 & 0.006 & & 0.001 & 0.001 & \\
\hline Developing & 0.006 & 0.006 & & 0.001 & 0.001 & \\
\hline Non-developing & 0.005 & 0.005 & 0.554 & 0.001 & 0.001 & 0.288 \\
\hline Beta & 0.136 & 0.144 & & 0.980 & 0.641 & \\
\hline Developing & 0.167 & 0.179 & & 1.697 & 0.728 & \\
\hline Non-developing & 0.122 & 0.098 & 0.449 & 0.649 & 0.641 & $1.910^{*}$ \\
\hline$R^{2}$ & & 0.046 & & & 0.174 & \\
\hline
\end{tabular}

Notes. In this table we display the aggregated results of our single-index model analysis. We present coefficient estimates regarding both the MSCI-National common share indices and regarding the GPR-General property indices. The estimates are based on five years of monthly observations for the period 1996-2000 and are reported as averages for clusters that have been formed with respect to the development involvement of the individual companies compared to their national average.

$\uparrow$ The $t$-statistic measures the statistical significance of the difference between the means of the property developing and non-property developing clusters. $T$-stats marked with $* *$ are statistically significant at a 95 percent level, while $t$-stats marked with $*$ are significantly different from zero at a 90 percent-confidence level. \$Development cohorts are based on the average size of the companies' development activities. Companies in the Developing cohort participate in development projects to an extent that exceeds the national sample average, Semi-developing are firms which do participate in development projects but to an extent that is less than the sample average. The Non-developing cohort contains companies that do not participate in any development projects at all. For the Hong Kong sample an exception has been made since all companies are involved in development projects. Therefore, we divided the Hong Kong sample into Highly, Medium and Hardly developing cohorts, which are based on the national sample means plus and minus 1 standard deviation of the development ratio. Due to sample size limitations we divided the French sample into two cohorts, the developing and the Nondeveloping cohorts.

Source. Global Property Research.

both the MSCI-National and GPR-General specifications. However, although these higher alphas for developing companies are consistent, they are not always statistically significant. For Hong Kong and Australia, we found the difference between the alphas of the developing and nondeveloping cohorts to be significant, but this does not hold for the other countries in the sample. 
With respect to the variations in risk we first document significantly lower beta estimates for our MSCI results, which corroborates with the notion that property shares exhibit relatively low market risk with respect to the overall stock market. Regarding the cross-sectional variations in the risk parameters both the GPR-General and MSCINational results provide the same patterns. With respect to firm's systematic risk, the beta, the results are the most distinct. For each national sample, we find the highest beta averages for companies that are involved the most in developing property. Moreover, we also find that firms belonging to the semi-developing cohorts have higher betas than firms that do not participate in property development at all. These cross-sectional patterns appear in both model specifications, indicating that property-developing firms tend to be more sensitive to swings in both the real estate and common stock markets. In order to quantify the significance of the differences between these cluster averages we also computed $t$-statistics that test equality in means between the developing and nondeveloping clusters. Table 4 shows that the GPR-General specifications offer the most significant patterns in stock performance: when we use that index as a proxy for the market, we find significantly higher betas for the developing cluster in all countries except for Australia. When using the MSCI as market proxy, we find similar patterns in the differences, but none of the differences we find is statistically significant.

In all five national samples the spread in stock performance has decreased significantly, with Hong Kong still containing the largest spread. In each sample the outperformance of the developing cohort has decreased and the relative performance of the nondevelopers has improved. The decrease of the spread in returns indicates that in each country at least a part of the strong initial relative performance of the developing companies is due to the difference in the underlying systematic risk.

\subsection{Multivariate regression}

While discussing the market statistics we already noticed that developing companies are associated with larger market capitalizations and higher debt levels. In order to analyze whether the variation in stock performance is not simply a result of these cross-sectional differences in debt financing and company size we need to control for such differences by performing cross-sectional multivariate regression analysis. We run the individual alphas and betas on the corresponding property development involvement levels, ${ }^{8}$ debt ratios, market capitalizations, and the MTB ratios. We also added a country dummy in order to incorporate the observed national differences. The output of our regression analysis is presented in Table 5.

Although our sample limitation hampers the statistical strength of our output, we document several interesting findings. With respect to the variation in individual alphas, property development involvement appears to be a significant explanatory parameter. In both model specifications we document significant and positive coefficients for the development variable, indicating that property development participations tend to increase the historic risk-adjusted outperformance. Furthermore we report negative coefficients for 
Table 5. Cross-sectional regression results.

\begin{tabular}{|c|c|c|c|c|c|c|c|c|c|c|}
\hline & \multirow[b]{3}{*}{ Constant } & \multicolumn{4}{|c|}{ Country Dummies } & \multirow{2}{*}{\multicolumn{4}{|c|}{ Factors }} & \multirow[b]{3}{*}{$R^{2}$} \\
\hline & & \multirow[b]{2}{*}{ U.S. } & \multirow[b]{2}{*}{ U.K. } & \multirow{2}{*}{$\begin{array}{l}\text { Hong } \\
\text { Kong }\end{array}$} & \multirow[b]{2}{*}{ Australia } & & & & & \\
\hline & & & & & & Dev. & DR & Size & MTB & \\
\hline \multicolumn{11}{|l|}{ Alpha } \\
\hline 3.1 & $\begin{array}{r}-0.001 \\
(0.002)\end{array}$ & $\begin{array}{c}0.001 \\
(0.002)\end{array}$ & $\begin{array}{c}0.001 \\
(0.002)\end{array}$ & $\begin{array}{c}0.001 \\
(0.003)\end{array}$ & $\begin{array}{r}-0.001 \\
(0.002)\end{array}$ & $\begin{array}{l}0.013^{* *} \\
(0.006)\end{array}$ & & & & 0.017 \\
\hline 3.2 & $\begin{array}{r}-0.001 \\
(0.002)\end{array}$ & $\begin{array}{c}0.001 \\
(0.002)\end{array}$ & $\begin{array}{c}0.001 \\
(0.003)\end{array}$ & $\begin{array}{c}0.001 \\
(0.002)\end{array}$ & $\begin{array}{r}-0.001 \\
(0.002)\end{array}$ & $\begin{array}{l}0.015^{* *} \\
(0.006)\end{array}$ & $\begin{array}{r}-0.004 \\
(0.003)\end{array}$ & $\begin{array}{r}-0.001 \\
(0.001)\end{array}$ & $\begin{array}{r}-0.001 \\
(0.001)\end{array}$ & 0.030 \\
\hline \multicolumn{11}{|l|}{ Beta } \\
\hline 4.1 & $\begin{array}{c}1.005 \\
(0.095)\end{array}$ & $\begin{array}{r}-0.006 \\
(0.102)\end{array}$ & $\begin{array}{r}-0.003 \\
(0.109)\end{array}$ & $\begin{array}{c}0.011 \\
(0.115)\end{array}$ & $\begin{array}{c}0.016 \\
(0.110)\end{array}$ & $\begin{array}{l}0.681 \text { ** } \\
(0.284)\end{array}$ & & & & 0.018 \\
\hline 4.2 & $\begin{array}{c}1.005 \\
(0.095)\end{array}$ & $\begin{array}{c}0.003 \\
(0.102)\end{array}$ & $\begin{array}{c}0.001 \\
(0.109)\end{array}$ & $\begin{array}{c}0.011 \\
(0.115)\end{array}$ & $\begin{array}{c}0.030 \\
(0.110)\end{array}$ & $\begin{array}{l}0.663^{* *} * \\
(0.290)\end{array}$ & $\begin{array}{c}0.020 \\
(0.128)\end{array}$ & $\begin{array}{c}0.021 \\
(0.013)\end{array}$ & $\begin{array}{r}-0.011 \\
(0.024)\end{array}$ & 0.026 \\
\hline
\end{tabular}

Notes. In this table, we report the estimates of the parameters for the models 1 and 2. These models relate the observed firm alpha, beta and sigma to dummy variables that indicate the country of origin and to development involvement (Dev.), the firm DR and firm size as potential factors. In order to control for the observed national variation in the average development involvement, firm size, leverage, and the MTB ratio we normalized these variables with respect to their country average.

Standard errors are given between brackets.

Coefficient estimates marked with ** are statistically significant at a 95 percent level, while estimates marked with * are significant only at a 90 percent confidence level.

In order to ensure that the inclusion of Hong Kong, where development involvement is remarkably high, is not driving our regression results we also ran the regression after excluding the Hong Kong sample. These control runs generates similar results with significant positive relationships between development involvement and firm risk at a 95 percent confidence level.

firm leverage, firm size and the MTB ratio, but these negative coefficients lack statistical significance.

Regarding systematic risk we again find a significantly positive coefficient for development involvement, which supports our previous findings that developing firms exhibit the highest betas. When adding firm leverage, size, and the book-to-market ratio into the model the sign and statistical significance of the development variable prevail. Although the coefficients of our control variables lack statistical significance the signs of firm leverage, size, and value coincide with the literature. Leveraging the firm seems to increase its exposure to the overall market while size exhibits a negative relationship with firm beta.

Overall, our regression results confirm the nature and strength of the relationships between the stock performance and development involvement, which we derived from the previous analyses. Again, we document a positive relationship between development involvement and firm risk, and a similar positive relationship is yielded for the riskadjusted historic stock outperformance. 


\subsection{Operational profitability analysis}

In this last section of our analysis, we investigate whether participation in development projects is also related to the operational profitability of a property company. All property companies in our sample are publicly listed and traded on stock exchanges around the world. These property shares may be prone to stock market sentiment and this creates the possibility that the performance patterns we have documented so far are merely a result of market whims instead of fundamental differences among the underlying companies. Therefore, we extend our analysis of the performance analysis towards operational profits. In other words, the question is whether property companies involved in development activities actually generate higher operational profits than their nondeveloping peers do. In order to answer this question we analyze the profit and loss accounts of the companies in our national samples and derive RCE, the ratio of pre-tax profits and net capital employed, as a measure for fundamental profitability. We gathered this annual profitability measure for each company in our sample for the period 1987-2000 from Datastream and present the periodic means for each cohort in Table 6.

The RCE-results in Table 6 exhibit steady fundamental profits of the property sector during the 1990s, with one severe downturn in the Hong Kong sample in the late 1990s due to the Asian crisis. For all the other country samples the operational profitability of the property sector has been fairly stable, with national averages in the range of 6-7 percent. The exception is the United States for which we used an RCE-proxy, by dividing operating profits by total assets, resulting in slightly lower numbers. Separating these national samples into development cohorts we find higher profitability figures for the developing cohorts than the nondevelopers for each national sample in booming markets, and slightly less favorable profitability figures in weaker markets. This finding coincides with our previous analysis, which already showed that the developing companies entailed more systematic risk, indicating a stronger sensitivity to overall market conditions. This can be interpreted as support for the observed positive relationship between development involvement and a firm's systematic risk.

\section{Conclusion}

This paper analyzed the economic effects of combining property investment with property development activities within one real estate company. Tax-exempt property companies are often precluded from participating in property development projects. In order to judge the economic sense of these measures, we analyze the performance of an international set of property investment companies who are to differing degrees active in property development. We studied the performance of 331 property companies from five international markets: the United States, Hong Kong, the United Kingdom, France, and Australia for the period 1987-2000.

Development participations were most common and most significant in size in our Hong Kong sample and most rare in our United States sample. These differences are partly due 


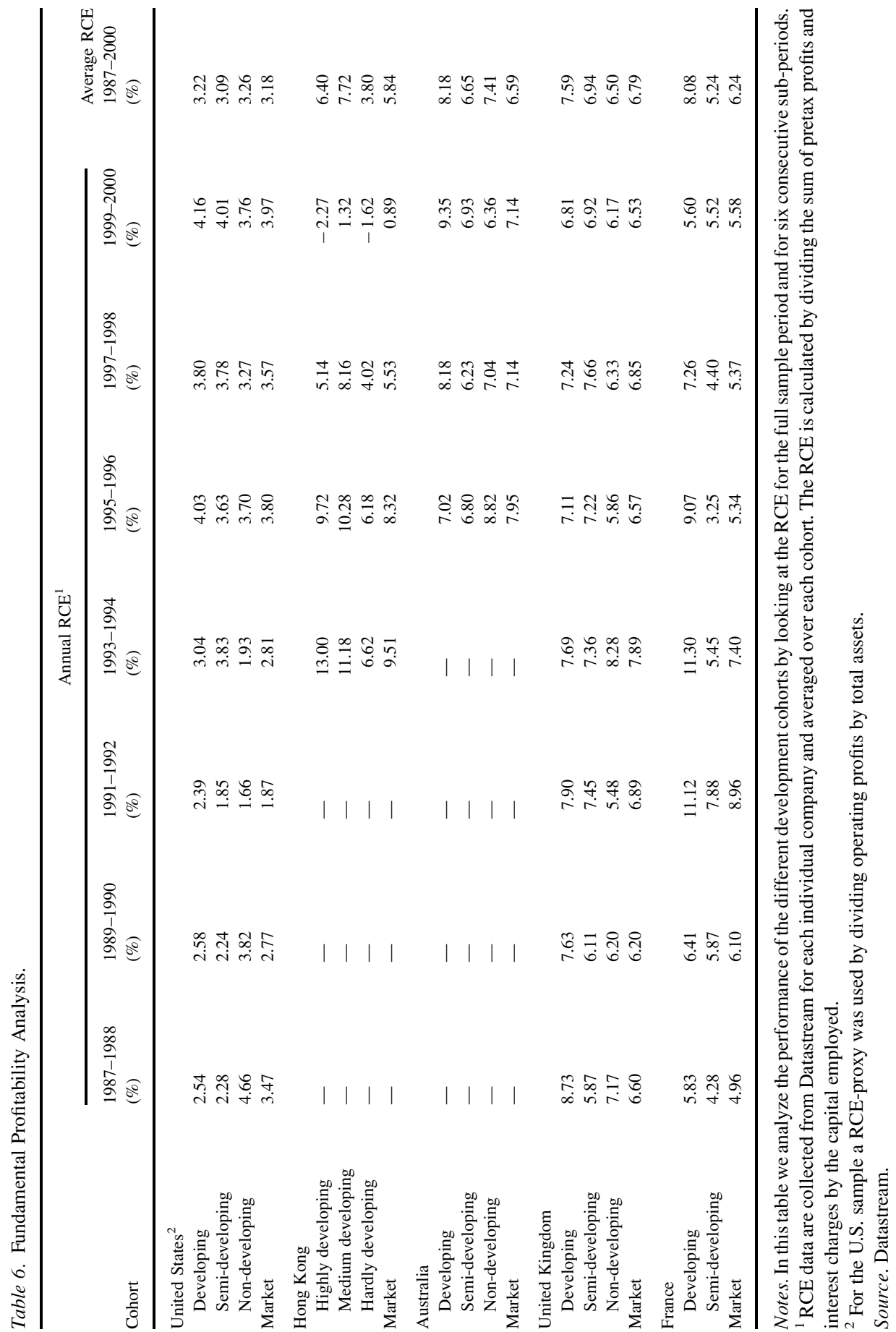


to differences in legislation that sometimes prohibit property investment companies from engaging much in property development projects by enforcing tax penalties.

Concerning stock performance we documented a positive and significant relationship between development involvement and firm performance. With respect to the risks we found a similar relationship. Especially the systematic risk of property companies appears to increase with the weight of the development activities. Combining these differences in return and risk we derived ex post risk-adjusted performance measures. These efforts resulted in performances that were more alike across the different development activity cohorts. In each market the initial outperformance of the developing companies decreased, resulting in a very mild and not statistically significant risk-adjusted outperformance for property developing companies. This result illustrates that part of the excess performance of the developing property companies was commensurate with the underlying risk. In order to abstract from the influence of possible stock market sentiments present in property stock returns, we also analyzed the underlying operational profits of the companies in our national samples. By deriving returns on capital employed ratios we obtained insights in the operational profitability of the firms in our samples. This analysis resulted in aboveaverage profitability ratios for the developing clusters during economic booms, while in soft markets property developing companies were associated with the lowest relative profits. This variation in market sensitivity illustrates the previously observed difference in the systematic risk profiles, which is higher for the developing cohorts in each market.

\section{Acknowledgments}

The authors thank Wylie Greig, Patrick Kanters, an anonymous referee, and participants to the 2001 meeting of the Real Estate Research Institute for their comments and thank the Real Estate Research Institute, the Association of Dutch Real Estate Researchers (VOGON) and the Netherlands Organization for Scientific Research (NWO) for financial support. We also like to thank Jeroen Beimer of GPR, and Lennart van den Kommer, Joop Kluft and the international network of Deloitte \& Touche for their helpful assistance. All remaining errors are the responsibility of the authors.

\section{Notes}

1. Property companies in countries without tax-transparency derive 16 percent of their total income from development activities, while that number is 2 percent in countries with tax-transparency for property companies. These numbers are based on the universe of property companies in the Global Property Research (GPR) Database.

2. The GPR Database collects and offers return information on all listed real estate companies in the world in a consistent manner.

3. We repeated these classifications on a bi-annual basis and reported hardly any companies that switched clusters over the sample period. Our results show that the involvement in property development is rather stable over time and since the classification is made relative to a dynamic national average level developers remained developers while semi-developers remained semi-developers. Shocks in the overall property development markets are absorbed by the variation in the national average level against which individual companies are classified. 
4. We include four dichotomous country dummy variables for the United States, the United Kingdom, Hong Kong, and Australia and omitted France in this model.

5. In order to control for the observed variation in national averages we normalized the property development ratio, firm leverage, firm size, and the MTB ratio with respect to the national averages.

6. Following the lessons from Fama and French (1995), we include firm size and the book-to-market ratios in order to capture the cross sectional return patterns that appear to persist between small and large firms and between high and low value firms. We obtained data on these variables from Datastream.

7. We apply the RCE ratio since it is computed consistently for international markets by Datastream Advance. The RCE-ratio directly relates effective profits to the asset base that has been applied in order to produce the resulting profits, hence offering a lean measure of operational profitability. Traditional measures like Return On Assets and Return On Equity do not always correct for extraordinary items and are based on a less accurate asset base and therefore would hamper a consistent international comparison.

8. Property development involvement is measured as the ratio of the book value of development projects and a firm's total assets.

\section{References}

Brounen, D., P. M. A. Eichholtz, and P. Kanters. (2000). "The Effects of Property Development Activities on the Performance of REITs," Real Estate Finance 4, 17-29.

Capozza, D. R., and P. J. Seguin. (1999). “Focus, Transparency and Value: The REIT Evidence,' Real Estate Economics 27, 587-619.

Chan, K. C., P. H. Hendershott, and A. B. Sanders. (1990). "Risk and Return on Real Estate: Evidence from Listed Equity Property Companies,"' Real Estate Economics 18, 431-452.

Denis, D. J., D. K. Denis, and A. Sarin. (1997). "Agency Problems, Equity Ownership, and Corporate Diversification," Journal of Finance 52, 135-160.

Eichholtz, P. M. A., and R. Huisman. (2000). “The Cross Section of Global Property Share Returns.” In J. Brown and C. Liu (eds.), A Global Perspective on Real Estate Cycles. Kluwer Academic Press.

Eichholtz, P. M. A., H. Op 't Veld, and M. Schweitzer. (2000). "REIT Performance: Does Managerial Specialization Pay?' In P. Harker and S. Zenios (eds.), Performance of Financial Institutions. Cambridge University Press.

Grenadier, S. R. (1995). “The Persistence of Real Estate Cycles,' Journal of Real Estate Finance and Economics 10, 95-119.

Jensen, M. (1969). 'Risk, the Pricing of Capital Assets, and the Evaluation of Investment Portfolios,' Journal of Business 42, 167-247.

Lewellen, W. (1971). 'A Pure Financial Rationale for the Conglomerate Merger,' Journal of Finance 26, 521-537.

Ling, D. C., and A. Naranjo. (2002). "Commercial Real Estate Return Performance: A Cross-Country Analysis," Journal of Real Estate Finance and Economics 24, 119-143.

Lintner, J. (1965). "The Valuation of Risky Assets and the Selection of Risky Investments in Stock Portfolios and Capital Budgets," Review of Economics and Statistics 47, 13-37.

Litt, J., and J. P. Mei. (1999). “'A Risk Adjustment Model for REIT Evaluation,', Real Estate Finance 15, 9-19. Markowitz, H. M. (1952). "Portfolio Selection," Journal of Finance 7, 77-91.

Montgomery, C. A. (1994). “Corporate Diversification," Journal of Economic Perspectives 8, 163-178.

Ross, S. (1976). “The Arbitrage Theory of Capital Asset Pricing,', Journal of Economic Theory 19, 425-442.

Sharpe, W. F. (1964). “Capital Asset Prices: A Theory of Market Equilibrium Under Condition of Risk,' Journal of Finance 19, 425-442.

Sharpe, W. F. (1966). “Mutual Fund Performance,', Journal of Business 39, 119-138.

Titman, S., and A. Warga. (1986). "Risk and the Performance of Real Estate Investment Trusts: A Multiple Index Approach," AREUEA Journal 14, 414-431.

Weston, J. F. (1970). “The Nature of Significance of Conglomerate Firms,'” St. John's Law Review 44, 66-80. Wheaton, W. (1987). “The Cyclical Behavior of the National Office Market,” AREUEA Journal 15, 281-299. ULI Market Profiles. (1990-2000). Pacific Rim, Unites States and Europe. Urban Land Institute. 